Jarosław Wołkonowski

\title{
Skargi mniejszości żydowskiej na arenie międzynarodowej na zachowanie się żołnierzy polskich podczas wyzwolenia Wilna w kwietniu 1919 r.
}

\begin{abstract}
Summary
In the middle of April 1919 Polish commander Józef Piłsudski decided to start a military operation to take Vilnius from Soviet hands. This fully successful operation was one of the first operations of the newly created Polish Army. Vilnius was liberated on April 21st 1919. During the fights 28 Polish soldiers and 60 Jewish civilians were killed. Jewish minority, the biggest in Vilnius, has written complaints to western Allies on illegal behavior of Polish Army during the fights. These complaints resulted with sending few international commissions to Vilnius. The documents referring to this question can be found in Jewish Scientific Institute in New York (YIVO). The most important are reports of Henry Morgenthau Commission from USA and Stuart Samuel Commission from GB. There are important differences in these reports. They show how complicated the national relations were in Vilnius at this time. The analysis of reports and Polish documents gives us an opportunity of full reconstruction of Vilnius events in 1919.
\end{abstract}




\section{Wstęp}

Pod koniec grudnia 1918 r. z Wilna wycofały się okupacyjne wojska niemieckie, a razem z nimi i Taryba ${ }^{1}$ litewska. Od 1 do 6 stycznia 1919 r. Wilno było bronione przez mieszkańców tego miasta, zorganizowanych w Samoobronie Wileńskiej. 6 stycznia opór wilnian został złamany, do Wilna i okolic wkroczyła Armia Czerwona, a w lutym 1919 r. utworzono Litewsko-Białoruską Republikę Sowiecką, na czele której stanęli przewodniczący: Vincas Mickevičius Kapsukas - ze strony litewskiej i Kazimierz Cichocki - ze strony białoruskiej. W połowie marca 1919 r. władze bolszewickie wyśledziły i aresztowały w Wilnie kilkadziesiąt osób z Wileńskiej Polskiej Organizacji Wojskowej². Osadzono ich w więzieniu na Łukiszkach i wszczęto śledztwo. 19 kwietnia 1919 r. Wojsko Polskie wkroczyło do Wilna, sam V. Mickevičius Kapsukas ratował się, jedynie w bieliźnie, ucieczką przez Zielony Most ${ }^{3}$. W toku tych walk o Wilno (19-21 kwietnia) bolszewicy uprowadzili kilku aresztowanych peowiaków z więzienia na Łukiszkach i w maju rozstrzelali w Dyneburgu ${ }^{4}$. Mniejszość żydowska, która w Wilnie była największą mniejszością, napisała skargi na bezprawne zachowanie się żołnierzy polskich podczas walk o Wilno. Skargi mniejszości żydowskiej odniosły taki skutek, że do Polski przyjechały trzy komisje międzynarodowe celem wyjaśnienia sytuacji i jej naprawy. Władze polskie uznały skargi mniejszości żydowskiej za bezpodstawne.

${ }^{1}$ Litewska Rada Narodowa (taryba lit. Rada) utworzona pod protektoratem Niemiec. Jako instytucja powstała w dniach 18-22 września 1917 r. w Wilnie podczas zwołanej konferencji Litwinów. Największym osiągnięciem Taryby było przyjęcie aktu niepodległości Litwy w dniu 16 lutego $1918 \mathrm{r}$. w Wilnie. 11 lipca 1918 r., w obawie przed Niemcami, Taryba proklamowała Litwę monarchią konstytucyjną i mianowała księcia wirtemberskiego Wilhelma von Urach królem Litwy - Mendogiem II. Po zmianie sytuacji 2 listopada 1918 r. Taryba odwołała swoją decyzję i proklamowała pierwszą tymczasową konstytucję. Taryba składała się z 20 członków. Wśród nich był jeden Polak, Stanisław Narutowicz (starszy brat Gabriela Narutowicza), który później wycofał się z Taryby w proteście przeciw uległości Niemcom. 2 stycznia 1919 r. Taryba opuściła wspólnie z niemieckimi władzami Wilno i przybyła wraz z nimi do Kowna, gdzie w kwietniu 1919 r. wybrała Antanasa Smetonę na pierwszego prezydenta Litwy. Swą pracę zakończyła 15 maja 1920 r. w momencie rozpoczęcia obrad przez Sejm Ustawodawczy Litwy.

2 B. Waligóra, Walka o Wilno. Okupacja Litwy i Białorusi w 1918-1920 przez Rosję Sowiecką, Warszawa 1938, s. 369-373.

3 „Głos Litwy”, 6 lipca 1919 r.

${ }^{4} \mathrm{~W}$ Dyneburgu zostali rozstrzelani następujący peowiacy z Wilna: Wacław Pac-Pomarnacki, Felicjan Dyszlonka, Zygmunt Kopernicki, Starża-Galiński. Ku ich czci w listopadzie 1928 r. stanął po prawej stronie wejścia na cmentarz Rossa tzw. Pomnik Dyneburżan, zniszczony w okresie powojennym. Zob. B. Waligóra, Walka o Wilno, op. cit., s. 442-443; J. Surwiło, Cmentarz Rossa w Wilnie, Wilno 1992, s. 5-6. 


\section{Wyprawa Wileńska}

W połowie kwietnia 1919 r. Józef Piłsudski wydał rozkaz przeprowadzenia operacji bojowej - tzw. Wyprawy Wileńskiej, która zakończyła się całkowitym sukcesem. Była to jedna $\mathrm{z}$ pierwszych wypraw bojowych nowopowstałego wojska polskiego, chociaż walki z wojskiem bolszewickim toczyły się już od kilku miesięcy. 21 kwietnia 1919 r. Wilno zostało wyzwolone ${ }^{5}$, lecz w najbliższych okolicach miasta w dalszym ciągu toczyły się walki ${ }^{6}$. Podczas walk o Wilno (w dniach 19-21 kwietnia) zginęło 28 polskich żołnierzy, których pochowano na cmentarzu Rossa ${ }^{7}$. Po kilku dniach (22-24 kwietnia) pochowano jeszcze 10 poległych, a w maju spoczęło tutaj jeszcze 76 polskich żołnierzy, którzy polegli w okresie od 25 kwietnia do końca maja 1919 r. $^{8}$

Po wkroczeniu 20 kwietnia 1919 r., w niedzielę, wojsk polskich do Wilna, na ulicach miasta ukazała się odezwa do ludności w czterech językach: polskim, litewskim, białoruskim i jidysz, wydana przez dowódcę Grupy Wojsk Polskich podpułkownika Władysława Belinę-Prażmowskiego, w której stwierdzano, że żołnierze Wojska Polskiego przynoszą „prawdziwą wolnośći równość”. 21 kwietnia 1919 r. na Wielkanoc, do Wilna przybył Marszałek Józef Piłsudski, gorąco witany przez wilnian, którzy masowo zgromadzili się przy Ostrej Bramie. Nazajutrz Józef Piłsudski wydał słynną odezwę Do mieszkańców Wielkiego Księstwa Litewskiego, w wersji dwujęzycznej, polsko-litewskiej ${ }^{9}$. Takie działania strony polskiej można wytłumaczyć odwołaniem się do potomków Rzeczpospolitej Obojga Narodów o wspólne działanie w odbudowie niepodległości Rzeczpospolitej. Jednak ta inicjatywa władz polskich nie znalazła zrozumienia i poparcia u nikogo poza polską grupą etniczną na tych terenach. Dalszą kontynuacją tej inicjatywy była propozycja Marszałka włączenia miejscowych grup etnicznych do władzy lokalnej. W liście do Premiera Ignacego Paderewskiego z 4 maja 1919 r. na temat wyzwolenia Wilna Józef Piłsudski pisał: „Ustanowiłem zarząd miasta w ten sposób, aby do niego wchodzili przedstawiciele nie tylko Polaków, ale i Żydów oraz innych narodowości. Tak, jak oczekiwałem, największy opór okazali Litwini, którzy po pewnych wahaniach odmówili wejścia do zarządu miejskiego. Żydzi

${ }^{5}$ Szerzej na temat akcji wyzwolenia Wilna zob. Komunikaty Sztabu Generalnego, „Monitor Polski” 1919, nr 91, s. 4.

${ }^{6}$ Więcej na temat walk w miejscowościach obok Wilna zob. Komunikaty Sztabu Generalnego, „Monitor Polski” 1919, nr 92-120.

${ }^{7}$ Wileńska Wielkanoc 20 kwietnia 1919 roku. Wystawa w 75. rocznicę odzyskania Wilna przez odradzające się Państwo Polskie po I wojnie światowej, Warszawa 1994, s. 13.

${ }^{8}$ Żołnierze ci polegli w walkach już po wyzwoleniu Wilna, walcząc z bolszewikami w okolicach tego miasta.

${ }^{9}$ „Monitor Polski” 1919, nr 95, s. 2 oraz A. Srebrakowski, Sejm Wileński 1922 roku. Idea i jej realizacja, Wrocław 1995, s. 18-19. 
zgodzili się na wydelegowanie wybranych przeze mnie delegatów, Białorusini wysłali zgodnie z żądaniem jednego" ${ }^{10}$.

Pierwszy raz Marszałek Józef Piłsudski otwarcie ujawnił swój stosunek do mniejszości żydowskiej w wywiadzie dla gazety „The Daily News” z Chicago 15 grudnia 1918 r., mówiąc o tolerancji i pełnych prawach wyborczych dla żydowskiej mniejszości w Polsce. Teza ta znalazła potwierdzenie w notatce Marszałka, pochodzącej z 18 grudnia 1918 r., w której zaznaczał, że Polska w swym pierwszym działaniu, ustawie wyborczej do parlamentu, nie może dopuścić ani jednego ograniczenia wobec mniejszości żydowskiej. Dotyczyło to także wyborów do samorządów. Podkreślił również, że wydane zostały rozkazy dla wojska, zapobiegające pogromom ${ }^{11}$.

22 kwietnia 1919 r. Marszałek napisał z Wilna list do ministra Stanisława Wojciechowskiego, w którym poruszał te kwestie: „Tutaj z trudnością powstrzymuję wojsko i tłumek od pogromów żydowskich, gdyż dotąd co dzień w tym lub innym miejscu z okien i dachów padają strzały i ręczne granaty, co naturalnie strasznie denerwuje zarówno żołnierzy jak i ludność" ${ }^{12}$. Do tego tematu powrócił w liście do Paderewskiego z dnia 4 maja 1919 r., opisując walki o Wilno: „Znacznie gorzej było z Żydami, którzy przy panowaniu bolszewickim byli warstwą rządzącą. $Z$ wielkim trudem wstrzymałem pogrom, który wisiał po prostu w powietrzu z powodu tego, że ludność żydowska strzelała z okien i dachów i rzucała stamtąd ręczne granaty" 13 .

Należy odnotować, że podczas wkroczenia wojska polskiego do Wilna miały miejsce zarówno wypadki rabowania ludności cywilnej, jak i strzelania

${ }^{10}$ Józef Piłsudski, Pisma zbiorowe, t. 5, Warszawa 1937, List do Ignacego Paderewskiego, s. 82. Do zarządu miasta, tuż po wyzwoleniu Wilna, zostało wyznaczonych trzech przedstawicieli żydowskich: Izaak Morgowicki, Adolf Gordon i Saul Trocki. Abram Załkind był mianowany kierownikiem Wydziału Handlu Magistratu miasta Wilna. O nominacjach tych osób do zarządu miasta Wilna zob. „Monitor Polski” 1919, nr 96, s. 3.

${ }^{11}$ W. Jędrzejewicz, J. Cisek, Kalendarium życia Józefa Piłsudskiego, t. 2, Wrocław - Warszawa - Kraków 1994, s. 32, 34. Pogrom (z ros. „zniszczenie”) - termin odnosi się przede wszystkim do grupowych napaści na Żydów lub na żydowskie dzielnice miast czy miasteczek. Zob. A. Unterman, Encyklopedia tradycji i legend żydowskich, Warszawa 2000, s. 217. Pogrom, jako zjawisko, nie jest dokładnie zbadane. Można wydzielić dwie fazy pogromu: 1 . Wstępna faza, gdy narasta napięcie pomiędzy grupami etnicznymi. Przyczyny napięć mogą być różne: ekonomiczne, socjalne polityczne i in.; 2. Napaści grupowe (określane są najczęściej jako pogrom), które wynikają z przyczyn przypadkowych, trudnych do przewidzenia. Klasycznym przykładem takiego pogromu był pogrom w litewskim miasteczku Leipalinga na pograniczu polsko-litewskim 18 czerwca 1939 r. Tego dnia po nabożeństwie w niedzielę, z powodu deszczu, sporo ludzi zaszło do sklepów żydowskich nieopodal kościoła. Istniejące napięcie pomiędzy litewską a żydowską grupą etniczną wywołało bójki pomiędzy Litwinami a Żydami oraz dewastacje sklepów żydowskich. Zob. D. Mačiulis, Anatomia jednego pogromu na Litwie: Leipalingi 18 VI 1939 r., [w:] Świat NIEpożegnany, Warszawa 2004, s. 605-611.

${ }^{12}$ Pilsudski Institute Archives, New York, Adiutantura Generalna Naczelnego Wodza, t. 16, s. 16.

${ }^{13}$ Piłsudski Józef, Pisma zbiorowe, t. 5, op. cit., s. 81. 
z okien i dachów do żołnierzy polskich. Co do pierwszych, jako przykład można przytoczyć skargę Rywki Aroks na kradzież dokonaną 21 kwietnia 1919 r. w mieszkaniu przy ul. Wielka Pohulanka 25 przez milicjana lub udającego go Kazimierza Moroza (w dalszej części podania R. Aroks zmienia nazwisko milicjanta na Morozow). Zaznacza także, iż wcześniej ta sama osoba obrabowała również sąsiadów Żydów. Aroks powiadomiła patrol polskich żołnierzy o tym rabunku. Kazimierz Moroz (lub Morozow) został zatrzymany, a zrabowane rzeczy zwrócono właścicielom: Głobus otrzymała wyroby ze srebra, Czerzok - wyroby ze złota, natomiast R. Aroks udało się odzyskać tylko część mienia. Na rozkaz polskiego oficera Kazimierz Moroz (lub Morozow) został rozstrzelany tego samego dnia, egzekucja odbyła się w podwórzu domu ${ }^{14}$.

Kolejnym dokumentem pozwalającym sądzić o wydarzeniach $\mathrm{z}$ tego okresu jest następujące zaświadczenie: „Zaświadcza się, iż mieszkaniec Wilna przy ul. Niemieckiej 37 Mote Straszun zapłacił 500 rubli (pięćset) jako karę za strzelanie do żołnierzy z okien jego mieszkania. Wilno. 19 kwietnia 19 r. J. Woroniecki ppor. 7 p. uł. W.P.” ${ }^{15}$. Należy stwierdzić, że grzywna 500 rubli była dosyć łagodną karą za takiego rodzaju wykroczenie podczas działań wojennych.

$\mathrm{Na}$ ogół ludność cywilna miasta Wilna radośnie witała wkraczających żołnierzy polskich. Tym niemniej ze strony cywilów odnotowywane były przejawy niezadowolenia w postaci strzelaniny z okien i dachów domów. Wśród cywilów, stawiających opór żołnierzom polskim, przeważali Żydzi ${ }^{16}$.

\section{Skargi mniejszości żydowskiej}

Jak podają źródła żydowskie, w toku walk o Wilno w dniach 19-21 kwietnia 1919 r. zginęło 81 wileńskich Żydów. Powyższe wydarzenie określa się mianem pogromu żydowskiego dokonanego przez walczące oddziały polskich legionistów ${ }^{17} .6$ maja 1919 r. na pierwszym posiedzeniu zarządu gminy żydowskiej miasta Wilnazostała przyjęta uchwała, w której stwierdzano, że „wielu niewinnych od dawna mieszkających Żydów, którzy absolutnie nie byli związani z walką wojska polskiego z bolszewikami, byli zabici bez śledztwa i sądu”. Dalsza część uchwały dotyczy tysięcy Żydów obrabowanych, aresztowanych i uwięzionych bez winy, bitych i poniżanych. Część więźniów została odstawiona do Lidy, a później wywieziona w nieznanym kierunku. Takie działania, według autorów tej uchwały,

\footnotetext{
${ }^{14}$ YIVO Institute for Jewish Research (dalej: YIVO), New York, RG 10, F 315, s. 9700.

${ }^{15}$ YIVO, RG 10, F 340, s. 8467.

${ }^{16}$ B. Waligóra B., Walka o Wilno, op. cit., s. 432-433.

${ }^{17}$ Jerusalem of Lithuania, illustrated and documented, collected and aranged by Leyzar Ran, vol. 1, New York 1974, s. 39.
} 
sformowały w społeczeństwie opinię, że „Żydzi są postawieni poza prawem i z nimi można zachowywać się jak się zechce”. Na zakończenie zarząd w imieniu żydowskiej gminy miasta Wilna zgłosił ostry protest władzom polskim ${ }^{18}$.

W tym okresie w zarządzie gminy żydowskiej miasta Wilna powołana została sekcja prawna, która zbierała oświadczenia i skargi poszkodowanych osób narodowości żydowskiej. Na podstawie zebranych materiałów sporządzono duże opracowanie pt. „Memorandum o wydarzeniach kwietniowych”, złożone 22 maja na ręce Generalnego Komisarza Ziem Wschodnich Jerzego Osmołowskiego. Zachowały się dwie redakcje memorandum. Pierwsza obejmuje wydarzenia od 19 kwietnia do 22 maja 1919 r. $^{19}$, druga zaś jest szersza i obejmuje okres od 19 kwietnia do 30 maja 1919 r. ${ }^{20}$ Szersza wersja, do której weszła w całości wersja pierwsza, została uzupełniona dodatkowo zebranym materiałem. Zgodnie z nią, od 19 kwietnia do 30 maja 1919 r. w Wilnie i okolicy zginęło ponad 60 osób pochodzenia żydowskiego ${ }^{21}$. Autorzy memorandum zwracają uwagę na to, że „nikt z wyżej wymienionych nie był wzięty z bronią. Niektórzy zostali rozstrzelani na miejscu, gdzie wzięci byli do niewoli. Część $\mathrm{z}$ aresztowanych w swoich mieszkaniach była odprowadzona na Lipówkę, reszta do innych miejsc i rozstrzelana tam bez sądu"22.

Inne raporty, opracowane przez sekcję prawną gminy żydowskiej, odnotowują następujące fakty: 19 kwietnia 1919 r. zginęła od kuli w podwórzu domu Krengla przy ul. Preobrażenskiej Maria Nieczupska ${ }^{23}$; 19 kwietnia 1919 r. z mieszkania K. Kolanskiego przy ul. Żmudzkiej 5/8 zabrano rzeczy i pieniądze na sumę 798 rubli, zabity został 12-letni chłopczyk ${ }^{24}$; Lejter Sz., ojciec dwóch dzieci, urzędnik sowiecki, popełnił samobójstwo w domu przy ul. Wielkiej $17^{25}$; jak podaje Benski Zusman, w Rudominie zastrzelono trzech Żydów, jednym z nich

${ }^{18}$ J.Wygodzki, In szturm (W burzy) (wspomnienia $z$ lat okupacji), Wilno 1926, s. 154-166. W proteście tym strona żydowska wystawiła następujące żądania: „1) Aby natychmiast skończyłby się rabunek majątku Żydów, aby została zapewniona nietykalność Żydów, honor Żydów, majątek Żydów, żeby były sformułowane uchwały prawne, za pomocą których Żydzi mogli kontynuować swe przedwojenne życie i działalność. 2) Aby w najkrótszym czasie zostali wróceni z powrotem wszyscy Żydzi, którzy bez wyraźnych dowodów ich winy byli wywiezieni z miasta. 3) Aby zostały znalezione gwarancje prawne, które dałyby możliwość aresztowanym wykorzystać wszystkie prawne możliwości dla udowodnienie ich niewinności. 4) Należy natychmiast zwolnić wszystkich aresztowanych, przeciw którym nie ma żadnych dowodów winy. 5) Należy podjąć kroki mające na celu odnalezienie zagrabionego majątku Żydów i ukaraniu rabusiów".

${ }^{19}$ YIVO, RG 10, F. 353, s. 19903-19916.

${ }^{20}$ YIVO, RG 29, F. 94, s. 19441-19467. Ten sam dokument zachował się w Bibliotece Litewskiej Akademii Nauk, Dział Rękopisów (dalej: BLANR), F. 255-549.

${ }^{21}$ YIVO, RG 29, F 94, s. 19441-19443, 19464.

${ }^{22}$ Ibidem, s. 19442.

${ }^{23}$ YIVO, RG 10, F 350, s. 20431.

${ }^{24}$ YIVO, RG 10, F 344, s. 19594 i strona odwrotna.

${ }^{25}$ YIVO, RG 10, F 343, s. 19497. 
był komisarz Berson ${ }^{26}$; 22 kwietnia 1919 r. we własnym domu w miejscowości koło Oszmiany został zastrzelony B. Abełtowicz, legioniści znaleźli w tym domu płaszcze wojskowe, które zostawili bolszewicy ${ }^{27}$; dnia 29 kwietnia $1919 \mathrm{r}$. obrabowano J. Lewina na sumę 1035 rubli, zabito jego córkę ${ }^{28}$.

Pierwsza część memorandum dotyczy około 400 Żydów zaginionych bez wieści, schwytanych w mieszkaniach, częściowo na ulicach, starych i młodych, kobiet i mężczyzn, odprowadzonych na dworzec, wsadzonych do wagonów i wywiezionych w nieznanym kierunku. Dopiero 7 maja 1919 r. została wysłana delegacja w poszukiwaniu tej grupy. Po upływie trzech tygodni wyjaśniło się, że niewielką część osób osadzono w więzieniach w Lidzie i Wołkowysku, natomiast 250 osób - w obozie w Białymstoku. Los pozostałych był nieznany; według autorów memorandum władze nie powzięły żadnych kroków w celu ustalenia ich miejsca pobytu ${ }^{29}$.

Sekcja prawna gminy żydowskiej miasta Wilna doliczyła się około 2000 rabunków, generalnie wskazując na żołnierzy polskich jako sprawców. Oto przykłady: S. Boguszinskiemu, zamieszkałemu przy ul. Zarzecznej 10/3, 21 kwietnia zabrano różne rzeczy na sumę 800 rubli $^{30}$; I. Lichtensztejnowi, zamieszkałemu przy ul. Sadowej 7/11 zrabowano rzeczy za sumę 10000 rubli, oficer zaś wystawił pokwitowanie na 4000 rubli z zarekwirowanych na potrzeby wojska ${ }^{31}$.

Na temat dokonywanych rabunków na ludności żydowskiej zachowały się liczne raporty, natomiast brak jakichkolwiek wiarygodnych dokumentów świadczących o mordowaniu osób pochodzenia żydowskiego. Należy przy tym stwierdzić, że brak protokołów dowodzących zabicie 60 Żydów uniemożliwia dziś postawienie zarzutu złamania rozkazów przez żołnierzy Wojska Polskiego. Nie można także wykluczyć pojedynczych wypadków „podszywania się” miejscowych mętów pod żołnierzy WP w celu rabunku lub osobistych porachunków.

Końcowa część „Memorandum” poświęcona jest prasie polskiej („Nasz Kraj” i „Dziennik Wileński”), która podaje zmyślone fakty, „tworzące opinię o znaku równości między Żydami i bolszewikami, przemilczając fakty, że wśród bolszewików są również Polacy, jak i Żydzi i że w armii czerwonej jest znacznie więcej Polaków, którzy walczą przeciw swym braciom, niż Żydów. (...) Przedstawicielstwo gminy gorąco protestuje przeciw kłamliwym oskarżeniom całej żydowskiej ludności w poparciu przywiązania się do bolszewizmu

\footnotetext{
${ }^{26}$ YIVO, RG 10, F 343, s. 19503.

${ }^{27}$ Ibidem, s. 19504.

${ }^{28}$ Ibidem, s. 19505 i strona odwrotna.

${ }^{29}$ YIVO, RG 29, F 94, s. 19441-19442.

${ }^{30}$ YIVO, RG 10, F 344, s. 19600.

${ }^{31}$ Ibidem, s. 19574.
} 
i w stawianiu oporu wojsku polskiemu. Ono oświadcza, że przetłaczająca większośćżydowskiej ludności wrogo ustosunkowała się do władzy bolszewickiej, opór zaś wojsku polskiemu był okazany wyłącznie przez komunistów bez wyróżnienia żadnych narodowości. Ludność żydowska jest sterroryzowana tymi wydarzeniami. Wbrew odezwie Naczelnika Państwa ono czuje się całkowicie bezbronną"32.

Doktor Jakub Wygodzki w swoich wspomnieniach pisze, że wśród aresztowanych byli znani działacze żydowscy: Samuel Niger i Lew Jaffe. Groziło im rozstrzelanie, gdyż żołnierze polscy oskarżyli ich o strzelanie z okien do Wojska Polskiego. Wygodzki osobiście zwrócił się o pomoc do prezydenta miasta Witolda Abramowicza i poręczył, że oni nie mają nic wspólnego $\mathrm{z}$ komunizmem oraz że nie strzelali do polskich żołnierzy. Prezydent obiecał pomoc $\mathrm{w}$ ich uwolnieniu. Zaproponował też, by Wygodzki, jako przedstawiciel Żydów, wszedł do ministerstwa, które miało zarządzać tymi terenami. Zdaniem Wygodzkiego, propozycja ta oznaczała uznanie suwerenności Państwa Polskiego, mimo że „pogrom wileński, co prawda w słabszej formie, ciągle trwał i życie Żydów i majątek były w dużym niebezpieczeństwie. (...) Polska i położenie całego kraju było niepewnym i brać udział w pracy rządu tego kraju oznaczało ryzykowanie losem Żydów na Litwie. Nie chcę wypowiadać swego zdania - pisał Wygodzki - jako jeszcze do niedawna członka rządu Litwy, jednak ja nie mogłem łatwo zgodzić się na pracę w ministerstwie i całkowicie nie zgadzałem się zostać ministrem". J. Wygodzki początkowo prosił o kilka dni do zastanowienia się, ale ostatecznie odmówił.

Kolejną próbą nawiązania współpracy z ludnością żydowską było powołanie przedstawicieli społeczności żydowskiej do komisji, która miała rozstrzygnąć kwestie wielu bezpodstawnych aresztowań. Z taką prośbą zwróciła się do Komisarza Ziem Wschodnich Jerzego Osmołowskiego delegacja żydowska. Władze polskie powołały taką komisję, do której ze strony społeczności żydowskiej weszli: dr J. Wygodzki, dr Cemach Szabad i dr Abram Makower. Jak pisze w swych wspomnieniach Wygodzki, „w tej ogromnej liczbie aresztowanych mieszkańców Wilna, w tej liczbie narodowości żydowskiej było kilka komunistów żydowskich, dokładnie wskazać na nikogo nie mogłem, ale ja nie miałem wątpliwości, że w 90 wypadkach na sto aresztowanych ludzie ci nie mieli żadnych powiązań z komunizmem, ani w ogóle z polityką. (...) Przez pierwsze dni pracy tego sądu udało się uwolnić niemało osób. Jednak trzeciego dnia wszystkie nasze starania, nawet nasze żądania, nie były brane pod uwagę". Dalej Wygodzki podsumowuje: „Władza polska względem Żydów stosowała politykę słodkich słów i gorzkich działań" ${ }^{33}$.

${ }^{32}$ YIVO, RG 29, F 94, s. 19466-19467.

${ }^{33}$ J. Wygodzki, In szturm, op. cit., s. 154-166. 


\section{Prace i raporty komisji alianckich $w$ sprawie skarg żydowskich}

Znane są skargi przedstawione przez stronę żydowską na arenie międzynarodowej mówiące o tym, że podobne wypadki miały miejsce jeszcze w kilku innych miastach Polski ${ }^{34}$. Napływające z Polski wiadomości o mających tam miejsce pogromach oraz chęć przeciwdziałania nasilającej się kampanii środowisk żydowskich zmusiły Ignacego Paderewskiego - ówczesnego premiera - dozwrócenia się do sekretarza stanu USA Roberta Lansinga w kwestii powołania komisji mającej wyjaśnić sprawę pogromów. 2 lipca 1919 r. Lansing powiadomił Paderewskiego, iż prezydent Wilson zatwierdził skład komisji. Weszli do niej: jako przewodniczący Henry Morgenthau - były ambasador USA w Turcji i aktywny działacz żydowskich organizacji filantropijnych, gen. Edgar Jadwin US Corps of Engineers oraz Homer H. Johnson - profesor prawa konstytucyjnego z Western University w Clevland. Zadaniem komisji było staranne zbadanie sytuacji ludności żydowskiej w Polsce, jej stosunków z ludnością nieżydowską, głównie z Polakami, okoliczności ewentualnych pogromów i ekscesów, bojkotu ekonomicznego i innych sygnalizowanych faktów dyskryminacji. Należało ustalić przyczyny leżące u podłoża ekscesów i dyskryminacji oraz złożyć konkretne propozycje ich zniwelowania ${ }^{35}$.

Podobnie jak władze USA zachowały się władze angielskie - brytyjski sekretarz stanu wysłał specjalną misję na czele ze Stuartem Samuelem. Obie misje (amerykańska i brytyjska) miały złożyć odpowiednie raporty dla swych władz w kraju. W międzyczasie (28 czerwca 1919 r.) Paderewski podpisał tzw. Mały Traktat Wersalski, który zobowiązywał państwo polskie do zapewnienia całkowitej ochrony życia i wolności wszystkich mieszkańców Polski. Traktat ten został ratyfikowany 31 lipca 1919 r. przez Sejm RP ${ }^{36}$.

13 lipca 1919 r. do Warszawy przyjechała Komisja Pokojowa z USA na czele z Henrym Morgenthau, w skład której wchodzili także gen. Edgar Jadwin i prawnik Homer H. Johnson, aby na miejscu zapoznać się ze stanem stosunków narodowościowych i kwestią żydowską w Polsce. Przyjazd amerykańskiej delegacji był zgodny z zasadami Małego Traktatu Wersalskiego i służył zbadaniu skarg mniejszości żydowskiej. 15 lipca 1919 r. odbyło się spotkanie Marszałka

${ }^{34}$ Są to następujące miasta: Kielce (11 listopada 1918 r. zginęło 4 Żydów); Lwów (w dniach 21-23 listopada 1918 r. zginęło 64 Żydów); Pińsk (5 kwietnia 1919 r. zginęło 35 Żydów); Lida (17 kwietnia 1919 r. zginęło 39 Żydów); Kolbuszów (7 maja 1919 r. zginęło 8 Żydów); Częstochowa (27 maja 1919 r. zginęło 5 Żydów); Mińsk (8 sierpnia 1919 r. zginęło 31 Żydów).

${ }^{35}$ http://www.niniwa2.cba.pl/CYTATY4.HTM

${ }^{36}$ „Monitor Polski” 1919, nr 171, s. 4-5; Dz. U. RP Nr 110 z 1920, poz. 728. 
Józefa Piłsudskiego z H. Morgenthau, podczas którego Marszałek wyjaśnił, że, jego zdaniem, w Polsce nie było pogromów, ale zdarzały się ekscesy spowodowane bardzo ciężką sytuacją ekonomiczną po kilkuletniej wojnie. Podkreślił także, że rząd przeciwstawia się wszelkim nadużyciom, niezależnie przeciwko komu są one skierowane. Nieco później, 2 sierpnia 1919 r., w Wilnie H. Morgenthau $\mathrm{w}$ towarzystwie gen. Jadwina po raz kolejny wymienił poglądy z Naczelnikiem Państwa. Była to dłuższa rozmowa na temat praw mniejszości narodowych w Polsce. Piłsudski odnotował bardzo negatywną rolę, jaką odgrywa w tej kwestii zachodnia prasa, która mocno wyolbrzymia ową sprawę. Podkreślił także, że postanowienia traktatu pokojowego odnośnie Rzeczypospolitej w omawianym temacie są błędne. Zdaniem Marszałka, odesłanie kwestii spornych pomiędzy obywatelem a państwem do ciała międzynarodowego czyni autorytet władz „niebezpiecznie nadwerężonym”"

Do następnego spotkania Marszałka z przewodniczącym komisji pokojowej z USA H. Morgenthau doszło 3 sierpnia 1919 r. w Lidzie. Po tej rozmowie H. Morganthau sporządził raport, w którym odpierał zarzuty zorganizowanych antysemickich rozruchów w Polsce. Podczas obiadu z Marszałkiem $\mathrm{H}$. Morgenthau zrelacjonował odbyte rozmowy z gminami żydowskimi na Wileńszczyźnie i zaproponował dowództwu dostarczenie ulotek w języku żydowskim z wezwaniem skierowanym do ludności żydowskiej o przychylne powitanie wojska polskiego w Mińsku. Odniosło to taki skutek, że w wyzwolonym Mińsku na uroczystości, w obecności Marszałka, między innymi przemawiał po hebrajsku przedstawiciel Żydów ${ }^{38}$.

Wskutek wydarzeń, jakie miały miejsce wiosną 1919 r. w drugiej połowie tego roku do Wilna przybyło kilka komisji międzynarodowych. Pierwszą była komisja kierowana przez H. Morgenthau z USA, drugą - komisja z Wielkiej Brytanii pod kierownictwem Stuarta Samuela, trzecią - komisja z Francji pod kierownictwem Reodela. J. Wygodzki dość niejednoznacznie ocenił w swych wspomnieniach pobyt oraz wyniki działania tych komisji ${ }^{39}$.

${ }^{37}$ W. Jędrzejewicz, J. Cisek, Kalendarium życia Józefa Piłsudskiego, t. 2, Wrocław - Warszawa - Kraków 1994, s. 92, 96.

${ }^{38}$ Ibidem, s. 97, 105.

${ }^{39}$ J. Wygodzki, In szturm, op. cit., s. 166-171 w następujący sposób opisuje każdą z tych komisji: „Komisja amerykańska, kierowana przez Morgenthau, przybyła do Wilna w ostatnich dniach lipca 1919 roku (...). Celem komisji było upewnić się, że pogromy miały miejsce i zbudować pokój. To jest uczynić wszystko, co jest możliwe, aby Żydzi i Polacy stali się przyjaciółmi. Komisja zwróciła się do gminy żydowskiej o udostępnienie materiału o pogromach, który został przedstawiony. Dla zbadania zebranego materiału komisja została podzielona na trzy podkomisje, które w przeddzień rozpoczęcia badań zwołały poszkodowanych i w dość ostrej formie przesłuchiwały. Przesłuchanie odbywało się w siedzibie gminy z udziałem przedstawicieli władzy polskiej (m.in. adwokat i komisarz miasta Jan Piłsudski) oraz przedstawicieli prasy Wilna i Warszawy. Celem komisji było wyjaśnienie wiarygodności skarg strony 
Amerykańska Komisja Negocjacji Pokojowych, której przewodniczącym był Henry Morgenthau, przebywała w Polsce od 13 lipca do 13 września 1919 r. Odwiedziła 8 miast, w których według skarg ludności żydowskiej miały miejsce przypadki mordowania ludności żydowskiej. Raport komisji został opublikowany w poniedziałkowym numerze dziennika „New York Times” 19 stycznia 1920 r. i wywołał protesty po obu stronach Atlantyku. Na wstępie swego raportu Henry Morgenthau stwierdził, że celowo nie będzie używał słowa „pogrom”, gdyż używa się go do określenia zarówno drobnych wykroczeń, jak i do przemyślanych oraz szczegółowo zorganizowanych masakr ${ }^{40}$. Z braku wyraźnej definicji tego słowa w raporcie H. Morgenthau (poza tytułem), używa słowa „excess” ${ }^{41}$. Dokonuje ekskursu do historii, przypominając że Polska w XII i XIII w. przyjęła na swe tereny Żydów z Niemiec i innych krajów Europy Zachodniej, gdzie byli prześladowani. Jego zdaniem, „w całej Europie jest znane, że Polska stała się schroniskiem dla Żydów i ich liczba zwiększała się jako wynik prześladowań w Zachodniej Europie”. Na skutek wypędzenia Żydów z Rosji pod koniec XIX stulecia ich liczba w Polsce jeszcze bardziej wzrosła ${ }^{42}$.

Według Morgenthau istotnym jest fakt, że w 1912 r. powstała w Polsce Narodowa Demokracja, która rozpoczęła kampanię antysemicką. Pod nieobecność rządu nowo powstałego państwa polskiego w listopadzie 1918 r., „przed przybyciem generała Piłsudskiego, który uciekł z więzienia niemieckiego",

żydowskiej i polskiej. Materiału zebranego przez gminę żydowską było tak dużo, że do zapoznania się potrzebne było wiele miesięcy. Dlatego też komisja ograniczyła swe badania do najbardziej znaczących wydarzeń. Komisja pracowała bardzo intensywnie kilka dni i wyjechała. Ja nie wiem, jakie wnioski przekazał Morgenthau prezydentowi Wilsonowi, jednak wiem, że wszystkie skargi wileńskich Żydów były uznane za słuszne i to jakim mianem je określono, czy pogrom, czy ekscesy nie ma większego znaczenia. (...) Przed odjazdem komisji zaproszono jej członków oraz przedstawicieli społeczeństwa żydowskiego do Naczelnego Komisarza Osmołowskiego, gdzie byli obecni również przedstawiciele władzy naczelnej kraju. Na tym pojednawczym posiedzeniu był obecny także przedstawiciel ministerstwa spraw zagranicznych, hrabia Żółtowski z Warszawy. Na posiedzeniu jeszcze raz pokazano, że Polacy względem Żydów prowadzą politykę ładnych słów, która nigdy nie przechodzi w czyny. Dwa miesiące później z Anglii do Wilna przybyła komisja kierowana przez Samuela. (...) Komisja Samuela powierzchownie zapoznała się z materiałem zebranym przez gminę żydowską, później przepatrzyła skargi Polaków o »bolszewikach «, »strzelaniu z okien« itp. Samuel nie był dyplomatą, dlatego jego sprawozdanie było proste i poprawne... Całkowicie inaczej usposobiona była francuska komisja socjalistyczna, kierowana przez znanego robotnika Reodela, który przybył do Wilna po kilku miesiącach po wyjeździe komisji angielskiej. W składzie tej komisji oprócz Reodela, który znał tylko język francuski, był niezależny przywódca socjalistów niemieckich Oskar Koin. Cała praca komisji francuskiej prowadzona była pod sztandarem walki z antysemityzmem ogółu i z nurtem antysemityzmu w Polsce".

${ }^{40}$ „The New York Times” 1920, January 19, s. 6, Fixes blame for Polish pogroms, p. 6.

${ }^{41} \mathrm{~W}$ języku angielskim słowo to oznacza „wykroczenie”, „wybryk”, nadmiar”, co w pewnym sensie odpowiada „eksces” w języku polskim. Eksces <łac. excessus - zboczenie, odstępstwo > 1. wybryk, wykroczenie, naruszenie porządku publicznego; 2. daw. nadmiar czego. Słownik wyrazów obcych, J. Tokarski (red.), PWN, Warszawa 1970.

${ }^{42}$ „The New York Times” 1920, January 19, s. 6, Fixes blame for Polish pogroms, p. 1-4. 
miał już miejsce pierwszy eksces. Ogółem, H. Morgenthau odnotowuje w raporcie 8 takich wypadków:

1. Kielce, 11 listopada 1918 r. zginęło 4 Żydów;

2. Lemberg (Lwów), 21-23 listopada 1918 r. zginęło 64 Żydów;

3. Pińsk, 5 kwietnia 1919 r. zginęło 35 Żydów;

4. Lida, 17 kwietnia 1919 r. zginęło 39 Żydów;

5. Wilno, 19-21 kwietnia 1919 r. zginęło 65 Żydów;

6. Kolbuszów, 7 maja 1919 r. zginęło 8 Żydów;

7. Częstochowa, 27 maja 1919 r. zginęło 5 Żydów;

8. Mińsk, 8 sierpnia 1919 r. zginęło 31 Żydów ${ }^{43}$.

Podczas tych ekscesów zginęło 280 Żydów.

Między 19 a 21 kwietnia 1919 r. w Wilnie Polacy stracili w walkach 33 żołnierzy; zginęło również 65 Żydów. Morgenthau wnioskuje, że „prawdopodobnie, żaden z nich [Żydów], spośród których były cztery kobiety i 8 starców, nie służył u bolszewików. Osiem Żydów zastrzelono bez śledztwa na przedmieściach Wilna 3 kilometrów od miasta. Inni zostali zastrzeleni przez żołnierzy, którzy rabowali budynki żydowskie”. W końcowej części raportu podaje, że „do 3 sierpnia 1919 roku, kiedy misja przybyła do Wilna, żaden z żołnierzy, lub cywilnych mieszkańców, odpowiedzialnych za te ekscesy nie był ukarany" ${ }^{44}$.

$\mathrm{Z}$ przedstawionych przez Morgenthau wniosków w końcowej części raportu wynika, że ekscesy w Wilnie zostały spowodowane przede wszystkim naruszeniem dyscypliny przez młodych żołnierzy Wojska Polskiego, przez brak doświadczenia wśród dowódców oraz zarzutów, że „Żydzi to bolszewicy”. Zdaniem przewodniczącego amerykańskiej komisji, za ekscesy w Wilnie nie ponosi odpowiedzialności cywilna ludność miasta, lecz polskie oddziały wojskowe.

Morgenthau zwraca uwagę na to, że miały też miejsce inne oddzielne przypadki, w których ginęli Żydzi, lecz ekscesy te nic nowego nie wnosiły do już wyżej wymienionych faktów. W ekscesach w Kielcach i Kolbuszowie wzięła udział ludność miejska i chłopi, w Częstochowie - ludność miejska i żołnierze Wojska Polskiego, we Lwowie, w Lidzie, Wilnie i Mińsku - żołnierze Wojska Polskiego. Ekscesy w tych miastach H. Morgenthau tłumaczy wyłamaniem się z dyscypliny młodych żołnierzy Wojska Polskiego i brakiem doświadczenia oficerów z dowództwa. Wnioskuje, że wypadki te nie były zaplanowane i że nie wolno winą za nie obarczać narodu polskiego. Za przykład pozytywnego rozwiązania konfliktów podaje Lwów, gdzie władze polskie tuż po wypadkach

${ }^{43}$ Ibidem, p. 5-6 oraz 1-8. Za początek ruchu narodowego w Polsce uważa się założenie w 1887 roku Ligi Polskiej, nazwę której w roku 1893 zmieniono na Ligę Narodową. Działacze w roku 1897 powołali Stronnictwo Demokratyczno-Narodowe.

${ }^{44}$ Ibidem, s. 7. 
rozpoczęly aktywne dochodzenie celem ujawnienia winnych tych zajśćc ${ }^{45}$. Omawiany powyżej raport został podpisany tylko przez $\mathrm{H}$. Morgenthau ${ }^{46}$.

Dwaj pozostali członkowie komisji, gen. Edgar Jadwin i Homer H. Johnson, mieli nieco odmienne zdanie na ten temat i przedstawili je w odrębnym raporcie. Piszą w nim, że militarne operacje, w wyniku których zdobyto Lidę (17 kwietnia 1919 r.), Wilno (21 kwietnia 1919 r.) i Mińsk (8 sierpnia 1919 r.), były źle zorganizowane, źle wyposażone, a dowództwo niedoszkolone. Nie wyróżniały się one niczym szczególnym, poza faktem, że ci, którzy zostali zabici oraz obrabowani, to praktycznie wszyscy Żydzi. W Wilnie walki uliczne trwały trzy dni, podczas których wojsko straciło 33 żołnierzy, cywili natomiast zginęło 65 - wszyscy cywile byli Żydami. Zdaniem autorów raportu, taka sytuacja wynikła z ogólnego przekonania, że „istniała aktywna sympatia dla bolszewików ze strony Żydów oraz ataków z ukrycia w czasie walk ulicznych, mamy wiele zeznań naocznych świadków. Nie ma wątpliwości, że w tej wysoce napiętej sytuacji jest wiele błędów po obu stronach" ${ }^{37}$.

Dalej gen. Edgar Jadwin i prawnik Homer H. Johnson zwracają uwagę na to, że wypadki, podczas których doszło do utraty życia, wymienione w raporcie H. Morgethau, miały miejsce w okresie, kiedy powstawało państwo polskie. Nie istniały wtedy jeszcze organy władzy polskiej, które miały za zadanie zapewnienie bezpieczeństwa ludności. Odnosi się to do wypadków w Kielcach i we Lwowie. Wydarzenia $\mathrm{w}$ Pińsku są ocenione $\mathrm{w}$ tym raporcie jako operacja wojskowa, która miała na celu sterroryzowanie żydowskiej populacji przez wykonanie wyroku na 35 Żydach w celu zastraszenia mniejszości żydowskiej. Przy czym była to samodzielna decyzja polskiego oficera, która nie została uzgodniona z dowództwem. Rozruchy w Częstochowie spowodowało publiczne ogłoszenie informacji o fakcie zastrzelenia polskiego żołnierza przez Żyda. Rozruchy zostały stłumione, jednak zginęło wówczas 5 Żydów. Ofiary te, jak piszą autorzy raportu, „były jedynymi śmiertelnymi wypadkami w Królestwie Kongresowym, w wyniku spontanicznej akcji motłochu od czasu, kiedy został utworzony stabilny rząd Rzeczypospolitej"48.

${ }^{45}$ Ibidem, p. 7-8.

${ }^{46}$ „The New York Times” 1920, January 19, s. 6, Fixes blame for Polish pogroms, p. 5 oraz Israel Cohen, Vilna, Philadelphia Jerusalem 5752/1992, s. 381.

${ }^{47}$ Amerykańska Komisja Negocjacji Pokojowych. Misja w Polsce, 66th Congress, 2d Session, U.S. Senate Document No. 177, Wasington 1921, http://homepage.interaccess.com/ netpol/ POLISH/historia/JadwinJohnson.html, s. 20 oraz The Jews in Poland, Official Report of the American and British Investigating Missions, The National Polish Committee of America, s. 15.

${ }^{48}$ Amerykańska Komisja Negocjacji Pokojowych. Misja w Polsce, 66th Congress, 2d Session, U.S. Senate Document No. 177, Washington 1921, http://homepage.interaccess.com/ netpol/POLISH/ historia/JadwinJohnson.html, s. 19. 
Końcowe wnioski gen. Edgara Jadwina i Homera H. Johnsona były następujące:

1. Powrót do normalnych stosunków w Polsce usunie większość niebezpieczeństw związanych z kwestią żydowską. Powrót ten nie zależy wyłącznie od dobrej woli Polaków. Ustanowienie pokojowych stosunków z Rosją to jeden z podstawowych warunków, aby państwo polskie znalazło się w normalnych warunkach funkcjonowania. Kiedy zniknie militarne niebezpieczeństwo, w Polsce zostanie stworzony system rządowy, który zapewni równość i bezpieczeństwo dla wszystkich obywateli;

2. Po 11 listopada 1918 r. miało miejsce w Polsce wiele godnych pożałowania wypadków. W Polsce Kongresowej wypadki te nie były bardzo poważne pod względem ilości śmiertelnych ofiar, lecz nosiły gwałtowny charakter; doszło podczas nich do zamieszek i pobić, podłożem których były uprzedzenia antyżydowskie. Wszystkie one zostały stłumione przez władze wojskowe lub cywilne, ale już po wyrządzeniu krzywd. Gorzej przedstawiała się sytuacja na terenach „okupowanych lub zajmowanych przez polskie wojska: motłoch postępował $\mathrm{w}$ ślad za wojskiem i oba te elementy angażowały się w rabunek sklepów i rezydencji i w wypadku trafiania na opór miały miejsce napady i zabójstwa". Żaden z tych wypadków nie uzyskał aprobaty ani władz wojskowych, ani cywilnych. „Z drugiej strony (...) podłoże historyczne i postawa Żydów, spotęgowana przez nienormalną sytuację ekonomiczną i polityczną z powodu wojny, dawała powód do antysemityzmu, zaogniała go w krytycznych momentach. (...) jednak (...) stopniowa poprawa warunków w czasie ostatnich 11 miesięcy jest bardzo obiecująca dla przyszłości Rzeczypospolitej jako stabilnej demokracji";

3. W Polsce istnieje antysemityzm, ale zakończenie wojny, ożywienie sytuacji gospodarczej i tolerancyjne usposobienie oraz samokontrola narodu polskiego pozwolą na zredukowanie tych zadrażnień;

4. Polska podpisała Mały Traktat Wersalski, który zawierał klauzulę odnoszącą się do mniejszości i zapewniającą wszystkim obywatelom „bezpieczeństwo życia i posiadłości oraz zabezpieczenie prawne" ${ }^{39}$.

Stuart Samuel przebywał w Polsce od początku września 1919 r. przez trzy miesiące. Jego raport potwierdza, że w Polsce w latach 1918-1919 miał miejsce szereg pogromów, które były ściśle związane $\mathrm{z}$ walką o niepodległość Polski. Odnośnie wypadków wileńskich z 19-21 kwietnia 1919 r. autor szacuje, że zginęło wówczas 55 Żydów. Z tego źródła wynika, że Wojsko Polskie oskarżyło Żydów o strzelanie do polskich żołnierzy i „oceniło wszystkich Żydów Wilna

${ }^{49}$ Ibidem, s. 21-23. 
jako wrogów i sympatyzujących bolszewikom"50. Stuart Samuel zamieścił także w raporcie swoje rekomendacje. Uważał, że rząd Polski powinien spełniać „w duchu sympatii” wszystkie wymagania Małego Traktatu Wersalskiego względem mniejszości żydowskiej, dbać o prawdziwą równość obywateli, publicznie nazywać i ukarać winnych przestępstw, ponieważ państwo wydaje wyroki nie z zemsty, lecz jako sposób zabezpieczenia się przed innymi przestępstwami. W sferze oświaty i gospodarki S. Stuart zalecał stosowanie zasady równości obywateli i odwołanie wszelkich aktów prawnych, niosących w sobie bojkot lub dyskryminację. Internowanym należało zapewnić opiekę lekarską; ich los miał być rozstrzygnięty przez sąd ${ }^{51}$.

Podobnie jak w przypadku komisji H. Morgenthau, komisja S. Samuela również nie była jednomyślna. Wraz z S. Samuelem przybył do Polski oficer angielski, kapitan P. Wright, który złożył raport dodatkowy. Oba te raporty zaopatrzył raportem wstępnym H. Rumbold, przedstawiciel Wielkiej Brytanii w Warszawie.

Większość zachodnich komisji oceniła wydarzenia, jakie miały miejsce w okresie 19-21 kwietnia 1919 r. jako ekscesy, winą za które obarczyła młode niedoświadczone Wojsko Polskie, odnotowując jednocześnie oskarżenia czynione ze strony polskiej o zaangażowanie się znacznej liczby Żydów wileńskich po stronie bolszewickiej. To są przyczyny, które spowodowały śmierć ponad 60 wileńskich Żydów i dużą ilość rabunków. Dowództwo Wojska Polskiego nie potrafiło podjąć adekwatnych działań, mimo starań o zmniejszenie ilości takich zajść. Skargi strony żydowskiej dotyczyły wyłącznie zachowania się żołnierzy polskich. Przedstawiła ona listę zabitych stwierdzając, że doszło do wielu przypadków nadużyć ze strony żołnierzy polskich, świadectwem czego są liczne skargi ze strony lokalnego społeczeństwa żydowskiego. Po zbadaniu listy zabitych można wnioskować, że ludzie ci zginęli pojedynczo w różnych miejscach miasta i w jego okolicach. Oczywistym wydaje się stwierdzenie, że zginęli $\mathrm{w}$ zamieszkach wojennych. Biorąc pod uwagę wnioski płynące z przedstawionych wcześniej raportów, za podstawową przyczynę tych zajść należy uważać brak zdyscyplinowania w młodym Wojsku Polskim. Tym można wytłumaczyć

${ }^{50}$ The Jews in Poland, Official Report of The American and British Investigating Missions, The National Polish Committee of America, Chicago, s. 28-29. Raport S. Samuela podaje, że według zeznań naocznych świadków: prezesa Sądu Okręgowego w Wilnie M. Zamczyckiego i wiceprezesa M. Bojko, żydowscy mężczyźni i kobiety przez dwie godziny strzelali do żołnierzy polskich na bulwarach Pohulanki i Aleksandrowskim. Zob. Z. M. Musialik, Wojna polsko-bolszewicka 1919-1920 a Żydzi, Częstochowa 1995, s. 39-42.

${ }^{51}$ The Jews in Poland, Official Report of the American and British Investigating Missions, The National Polish Committee of America, Chicago, The Samuel Report, s. 31. 
wiele przypadków niegodziwego zachowania się żołnierzy, przy czym trzeba odnotować negatywne nastawienie żołnierzy polskich do ludności żydowskiej.

\section{Uwagi końcowe}

Dnia 29 października 1920 r. minister spraw wojskowych gen. K. Sosnkowski odpowiadał w Sejmie RP na zarzuty posła Icchaka Grünbauma o nieodpowiednim traktowaniu ludności żydowskiej przez Wojsko Polskie. W swym wystąpieniu Sosnkowski powiedział, że rząd Polski traktuje bezstronnie i na równi wszystkich obywateli tej ziemi, którzy lojalnie w stosunku do państwa spełniają swoje obowiązki. Jako dowód przytoczył opublikowaną w prasie listę 17 osób skazanych na śmierć za łamanie prawa obowiązującego w Polsce. Miało to przekonać, że wszyscy ci, którzy dopuścili się gwałtów i rabunków na ludności żydowskiej, zostali ukarani. Poseł Grünbaum twierdził, że ogółem wydano 13 wyroków śmierci, na co Sosnkowski odpowiedział: „Różnica cyfrowa, na którą się $\mathrm{w}$ tej chwili pan poseł powołuje, wynika stąd, że przy wyrokach śmierci, których cyfrę przytaczam, parę wyroków odnosiło się do żołnierzy Żydów, którzy dopuszczali się gwałtów i rabunków nad Żydami”"52.

Dokumentacja strony żydowskiej, zachowana w archiwum Żydowskiego Instytutu Naukowego (YIVO) w Nowym Jorku, umożliwia spojrzenie na owe wydarzenia od strony żydowskiej społeczności Wileńszczyzny. Bardzo ważne są w tym zakresie raporty komisji Henry'ego Morgenthau z USA i Stuarta Samuela z Wielkiej Brytanii. Komisje te przybyły do Polski na skutek skarg żydowskich. Rozbieżności wśród ekspertów tych komisji, jakie powstały w czasie prac komisji zachodnich i podczas sporządzenia raportów, jak również brak wspólnego stanowiska tych komisji, ukazują złożoność materii stosunków narodowościowych. Zarówno raporty zachodnich ekspertów, jak i materiały strony żydowskiej oraz polskiej pozwalają na obiektywną, krytyczną, ocenę akcji wyzwolenia Wilna w kwietniu 1919 r. Incydenty, jakie miały miejsce w tym okresie były spontanicznym, ubocznym, niezamierzonym skutkiem walk o niepodległość Polski.

${ }^{52}$ Pilsudski Institute Archives New York, Wojny polskie, t. 2. Sprawy żydowskie, 180 posiedzenie Sejmu z dnia 29 października $1920 \mathrm{r}$. 